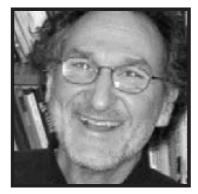

\title{
Of Jaguars, Anthropologists, and Cole Porter: Poetry \& Revision
}

\author{
David Cappella, Central Connecticut State University
}

\section{ABSTRACT}

The educational purposes of examining the revision process of a specific poem are significant and, to me, profound. It is a specialized teaching tool, one that burrows into the workings of the imagination by encouraging students to ponder specific changes to the various drafts and to discuss them. Such language talk about changes and close reading explicitly reveals those decisive steps that a poet takes in order to allow the real poem to emerge.

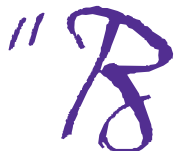
irds do it, bees do it/Even educated fleas do it," and as a person who grew up on Cape Cod, I know that "clams, 'gainst their wish, do it" (Porter, 1928). I would add to Cole Porter's song line, "Poets, givin' their heart to a poem, do it." I am not speaking necessarily of falling in love, as Cole Porter most definitely does, although no one would deny that poets are right up there with birds, bees, and clams in that regard. To give a poem true affection, poets do something else to it, something akin to falling in love, I suppose-they revise it.

The process of revision: the act of re-seeing a poem; the process of the writer, after drafting a poem, asking, what Baron Wormser and I ask in our book, $A$ Surge of Language: Teaching Poetry Day by Day (2004): "What if? What if I change this to that? What if I take line four out? What if I add some more adjectives? What happens?" (p. 56). "The ' $R$ ' word" (p. 54). What is this act of revision, this singular process that elevates the poem from a mere act of self-expression to a work of art, to a finished piece with a purpose? That is, what does it mean to "revise" a poem? We know that revision for students can be a challenge, to put it mildly. After all, they want to 
express themselves. They think if they express themselves in a poem, it must automatically be good. As we note, "the first draft is an impulse and impulses matter powerfully" (p.57). Often for students, expression is all.Thus, all too often, they do not want to take that next step. They do not want to deal with the actual poem that they have produced. They cannot see it as a newly formed object on the page, and, as such, an entity in and of itself.

And to revise a poem demands that the writer "see" the poem qua poem. As Baron and I ask our students, "What if the poem wants to be honored as a poem, as a potential work of art that wants to be all it can be?" (p. 55). Revising asks the writer, any writer, student or professional poet, to determine what the poem really wants to be and where the poem really wants to go. Regarding the writing of poetry, the ultimate question becomes: "What is there to revise in a poem?"

There's a lot to revise, as we all know. "Word choice, structure, syntax, form, point of view, metaphor" (p. 56), just to name a few aspects of a poem that must be considered. There are a myriad "what if" questions that, in terms of classroom pedagogy, become interesting for peer revision and general revision tasks. Here are a few: "What if one moment in the poem is expanded/shortened? What if the verb tense changes? What if the poem begins at a different place?" (p. 58).

As Baron and I point out, the educational dimension of revision can be explored in many ways as it allows the student to follow any path he or she deems necessary to improve a draft. We do give students a list of specific suggestions to guide them through the revision process. But it is important to keep in mind that "it isn't prescriptive and it isn't all-encompassing" (p. 59). The suggestions create interest in the poem and in poetry in general.

This is why when I teach the writing of poetry, whether to teachers or to students, I usually present an intensive session on revising and rewriting. I take them through the various stages of rewriting of a poem that I wrote, usually a poem that I have been working on for a few months or longer. With each version of the poem (I have scads, as I chronically revise every poem), I give a brief commentary on the revising strategy I adopted for that poem, analyzing salient points in the poem where revising changed the draft to bring out the "real" poem. Students are free to respond and comment on these various revision decisions. Teachers and students learn a lot about discovering the poem that often lies beneath the drafted poem, as Lucille Clifton would say. 
By discussing and analyzing how a specific poem is revised, both the teacher and the student, as they tease out the whole revision process, begin to profile the relationship between imagination and rhetoric, so to speak. That is, when one examines the revision decisions of a poet regarding a specific work, one begins to see how the poet shaped ideas with words. Just take a look at the poet Robert Lowell's detailed revisions of his poems to see how imagination solidifies into rhetoric.

Examining a poet's revision process has many benefits. Doing so allows one to experience the poem from its inception. One becomes familiar with the work by examining its language. Assumptions about words are raised. One notices that some assumptions about the poem are false, while others are true. An idea of the poem begins to emerge, a sense of what it is about, what it is trying to do, and why it takes its particular shape. Initial exploration of the revising process fosters further analysis. As the poet redrafts a poem, each draft asks to be examined more intensely since every new revision, in effect, creates a new poem. Even the subtlest change profoundly alters a poem. As this process replicates itself with each new draft, one examining the process is left to wade deeper and deeper into the poem. ${ }^{1}$

Baron Wormser has often said that young writers (and lots of established poets, too!) tend to quit too early on in the revision process and so never get deeper into the poem. Thus they miss the real poem that lies within. By examining the stages of a poet's revising process, students can witness this in-depth exploration for themselves. And this is a personal endeavor, a subjective engagement with language. A poet friend and creative writing teacher, Jim Provencher, defines this encounter with revision for his students this way: "You meet the poem, you get to know it, you make assumptions, some false, you try to grow it like a self that emerges" (J.Provencher, personal communication, August 10, 2010).

Above all, examining the revision process allows students to come to terms with the time it takes to revise a poem. They get to experience how spending time on the draft of a poem distills and develops perspective. Such an experience induces reflection. ${ }^{2}$ And such reflection focuses on the series of decisions made during the revision process. For these reasons, actively demonstrating how a poem is revised enables students to "see" the process in action, to actually participate in it, even though it has already occurred. By discussing and analyzing the various versions of a poem, by commenting on the decisions made by the writer in each version, students have the opportunity to create their own account of the revision. In other words, their personal commentary, as they discuss and assess the poet's revisions, enhances their understanding of revision. 
The educational purposes of examining the revision process of a specific poem are significant and, to me, profound. It is a specialized teaching tool, one that burrows into the workings of the imagination by encouraging students to ponder specific changes to the various drafts and to discuss them. Such language talk about changes and close reading explicitly reveals those decisive steps that a poet takes in order to allow the real poem to emerge.

For the revision exercise, as I stated above, I use a poem I have been working on for a few years. It was most recently used with a group of pre-service English students taking an English Methods class at an urban state university. I have chosen five versions of the poem. They are: UR-version, Version I, Version IV, Version VI and Version VII. The commentaries accompanying each version appear in italics. They represent a shortened version, impromptu shorthand so to speak, of what I might say to initiate discussion about the particular draft in order to trigger comments about the process of revising itself.

\section{[UR Version]}

\section{When the Shaman Kills the Jaguar}

the shaman dissolves into the jungle's void

leading himself to a certain tree

where he sat and leaned against its trunk.

He chanted the jaguar to him.

The jaguar came as the shaman

What did both sets of eyes glimpse?

At the moment man and animal gazed

into the retinal fire of the other?

what profound sight did each traveler witness?

Did all things invisible become visible?

Did each drown in a vitreous sea of fear?

Did they careen down through cavernous innards

helplessly falling toward a shivering soul?

Did the shaman aim a question that struck

the jaguar like an arrow, locking his legs,

bowing his head in wounded reverence? 
One fact is certain: the shaman asked to kill the jaguar.

It was a deferential "May I kill you?"

Beauty, strength, and force acquiesced because

to live or to die is a submission to the world.

The jaguar crushed the rifle bullet as much as it crushed his skull.

Nature is every movement that we make.

life's hemorrhaging feelings

Dreams coat the Shaman's mind the way the taste

of oregano or a pine nut

That coats the mucused skin inside your mouth,

Nature abounds in every movement

That we make and so the jaguar crushed.

This version is the absolute beginning of a poem. It is the impulse put a feeling into words. In fact, this initial version is straight out of my journal. Background: A colleague, an anthropologist who works with the Yanomami Indians deep within the Brazilian rain forest, told me a story about a jaguar that was prowling their territory, had snatched some chickens, and had recently injured a hunter from the village. The tribe was afraid the cat would take a child, so the shaman had to "bring" the animal to be killed. In celebration, the tribe skinned the cat, then cooked it and ate it. My colleague arrived the day of the feast, and she partook of the meat.

As one sees from the title, the idea of the shaman killing the animal interested my imagination. I was captivated by how the animal was "caught" by the shaman. One can see from the notes that I began the poem by describing the events. But one can also see that my imagination wanted to go further because I began asking questions not only about the shaman but about the jaguar as well.

Now, this asking of questions about the jaguar seems very Blakean to anyone who has read "The Tyger," but we do not have to go there now. I mention it only as an instance of how the imagination works, how one's reading settles into the mind and becomes activated when certain images or ideas from experience interact with it. The ideas in the poem are obvious: the jaguar submitting to his own death; nature as movements that we make; the idea of dreaming appears, as does the soul. Something else is 
going on in this preliminary draft worth noting: odd words or phrases appear: "vitreous," "pine nut," "oregano," "bullet," "hemorrhaging." Also, the draft falls off into fragments, detailed images, and figurative language.

Obviously, this version is not really a draft. It is an attempt at a draft. It is a basic imaginative impulse to deal with a story that was told, an attempt to chronicle an incident. Yet, it is more that that. It is an attempt to urge to peek inside the story, to explore some emotional truth behind it, maybe.

In any case, there are many, many questions: Are their any images, lines, or words worth keeping? Is a form emerging from the manner in which the lines were grouped? From this jumble of ideas and images what can be forged, if anything? And how does one begin?

With this initial draft, students begin reading to discuss the inception of a poem, that is, how one gets an idea for a poem. They become intrigued with the idea of what makes a poem, of what interests a poet, and why. They discuss what direction they think the writer will take, given this initial attempt to capture a feeling.

\section{[Version I]}

\section{Riding the Jaguar}

Certain problems arise.

A jaguar has killed a chicken, then a dog.

Two Yanomami hunters heard its growl.

A lone hunter was mauled; children are in danger.

Hunted for days, the jaguar's lair was not found.

Problems thick as the rain forest are a Shaman's task.

He called the jaguar to him late one night.

He disappeared into the jungle,

leading himself to a certain tree

where he sat and leaned against its trunk.

The jaguar came as the shaman stared into the dark.

What did both sets of eyes glimpse?

At the moment man and animal gazed 
into the retinal fire of the other

what profound sight did each traveler witness?

Did all things invisible became visible?

Did each drown in a vitreous sea of fear?

Did they careen down through cavernous innards

helplessly falling toward a shivering soul?

Did the shaman aim a question

that struck the jaguar like a poisoned arrow

locking his legs and lowering his head?

One fact is certain: the shaman asked to kill the jaguar.

It was a deferential "May I kill you?"

Beauty, strength, and force acquiesced because

to live or to die is a submission to the world.

The jaguar crushed the rifle bullet as much as it crushed his skull.

The jaguar's body: held up and displayed, measured and danced around, skinned, his meat eaten by the entire tribe.

The anthropologist ate the meat, too.

Later that night, beside a dying fire, she wrote,

"Magic happens every night and every day."

Later still, fading into sleep, a thought

scampered cat-like across her mind:

Nature is every movement that we make.

Nothing is a dream $\neg$

even if a jaguar visits in your sleep.

A dream, like the taste of oregano or of a pine nut,

lingeringly tinges the mucused skin inside your mouth.

Like a flavor, it abounds.

Nothing is a nightmare

even if the jaguar, muscles rippling,

froth dripping from his jaws,

his Blakean eyes burning yellow-deep,

stares into your aorta or lopes into a ventricle

hunting your soul, his powerful claws

scratching your veins as he lingers,

smelling for the soul's musky scent. 
As she watches in her sleep, the jaguar leaps,

runs down her soul and with one swipe

mauls it like some jungle peccary.

His spike-like eyes transfix her, his crouch

on padded feet, his sudden spring and gapping jaws.

His bite into her soul carries a fear

which ripples down into her bone marrow.

He rends it, shaking it from side to side.

Her soul's peculiar dangle from his mouth.

Her soul's limp bounce as he drops it.

He nudges its carcass with his nose, rolls

on it, arching his back. He trots away

to a private place to devour his catch,

a true and mysterious meat.

Swaying slightly in her hammock, eyes wide

and surrounded by night, the anthropologist

recalls leaning down from his back to sniff

his eyes and mouth, to touch his stark whiskers;

recalls the raspy gush of his deep breath

as he ran her full stride into her heart,

straight into her life's bloody miasma

where her true feelings hemorrhage

where inside each blood cell her soul laments.

After a period of a few days, I did try to make some sense out of the UR Version. I gave my notes a narrative form, adding details and a chronology. I added a reportorial perspective, thinking that such a stance would narrow the scope of the subject for the reader. So, in effect, I tried to give a form to the poem, and I tried to connect the form to the reader. I was thinking of audience. It was as though I was talking to the reader.

I also went further. After telling the story, I began a sort of disquisition about it. Beginning with "Nothing is a dream," I veered off into the idea of the anthropologist dreaming about the jaguar. I wanted to explore, obviously, the effect of eating such an exotic animal, maybe? Or, I thought that the emotional state of the anthropologist made the poem more personal for the reader, maybe? 
Version I is more of a shaped piece, an actual draft, however spotty in terms of lines or rhythm or conflated and confused images. It is interesting to note that from the line "Nothing is a nightmare," the poem wants to be about the anthropologist's dream and its effect on her as she sleeps and just how eating the jaguar's flesh affected her soul. I am veering away from the shaman and toward a new topic by the end of this version. This is obvious because I have retitled the draft to focus attention on the anthropologist's dream where she is riding the jaguar.

The image of the anthropologist swaying in her hammock seems like a keeper. Also, the whole extended image of the jaguar in her dream preying upon her soul seems worthwhile, but is it rendered well? The stanza seems too weighty in the sense that it is too crowded with images.

There are some horrible lines that must be excised at some point. One notable one is, "It was a deferential 'May I kill you?'" No comment needed here. It is amazing what a writer will do, what odd particulars he or she writes down in order to capture the whole. Still, this draft has a flow to it. It has a beginning and end and it seems to be coalescing into a narrative poem. Maybe.

With a look at Version I, students begin to tackle the structure of a poem, keeping an eye on what the poet is trying to say, and whether he or she is saying it. With this version, students begin the true work with language. They can see word choices, how certain lines might work or not. A myriad of questions arise as they try to decipher the poet's intention and try to find the actual poem.

\section{[Version IV]}

\section{When the Anthropologist Ate Jaguar Meat}

Choice is a poisoned dart. In the jungle, where nothing is a dream and nothing is a nightmare, when night strikes and fires blaze, the dead cat cooked. Amid shouts and dancing, the anthropologist swallowed the meat. Later that night, beside a dying fire, she wrote, "Magic happens every night and every day." 
Later still, as she fades into sleep, the jaguar leaps,

runs down her soul and with one swipe

mauls it like some jungle peccary.

His spike-like eyes transfix her: his crouch

on padded feet, his sudden spring and gaping jaws.

His bite into her soul carries a fear

which ripples down into her bone marrow.

He rends his prey, shaking it side to side:

her soul's limp bounce as he drops it,

as he nudges its carcass with his nose,

as he rolls near the broken neck, arching his back;

her soul's peculiar dangle from his mouth,

as he trots away to a private place

to devour his catch, the true, mysterious meat.

She sways slightly in her hammock, eyes wide now in the surrounding night. A feline dream scampers through the anthropologist's mind.

She recalls leaning down from the jaguar's back

sniffing his eyes and mouth, touching his stark whiskers,

recalls the raspy gush of his deep breath

as he runs her full stride toward her own heart,

that miasmal landscape of lamenting

where her spirit, thralled, alone, witnesses

the chewed bones of her emotions now strewn,

splintered, blotched red with clotted drops of love.

Here, we jump into a tighter, more focused version of the poem. Now a fullfledged draft (and students discuss how to distinguish a solid draft from one that is not so solid), the poem, as indicated by, among other reasons, yet another title, ${ }^{3}$ both strangely startles and directs the reader. The poem has been cut down, telescoped so to speak. I have begun to explore the inner world of the anthropologist, excising the shaman and how the jaguar was killed. I had overwritten terribly. But where would I have been if I did not do that? Students are curious about this idea of writing too much. They want to know how one knows when one is overwriting. Here they have this draft to compare to the previous draft to figure this out. 
Now I have a poem of four seven-line stanzas and a four-line ending stanza. The rhythm is steady, conversational. Each line has four or five beats. The narrative is condensed. The poem begins with a metaphor, a solid image. I rewrote and rethought the opening of the poem and basically discarded each version. They were not the poem. They were a warm-up, written, it now appears, to arrive at the effects of jaguar meat on the anthropologist. Whether this was a good move or not, it was a decision that I made in my revising process. And, I did stick with it, as you will see. Again, students discuss this decision and come to see that decisions are important, and each decision builds upon a previous one.

What most concerns me in this draft is the ending, with which I am still having grave problems. Some lines continue to embarrass: "that miasmal landscape of lamenting." Okay, I like the sound of this line, but, I mean, does the line actually work, given the rest of the stanza? Actually, does this last, short stanza really work at all? I think we all agree that it misses the mark. Aside from being a bit over the top, structurally it directs the reader away from the emotional state of the anthropologist and to the jaguar in the dream. The poem does not want that, does it? The poem wants the focus on the anthropologist.

Such analysis brings the student deeper and deeper into the structure of the poem in relation to what the poem wants to say, wants to be. It is important to note that students arrive at this point organically. They have begun with a journal entry, an impulse, and by this version, they are questioning whether stanzas of the poem are necessary or, if they are, whether they are well written.

\section{[Version VI]}

\section{When the Anthropologist Eats Jaguar Meat}

Choice is a poisoned dart. In the jungle, where nothing is a dream and nothing is a nightmare, when night strikes and fires blaze, the dead cat cooks. Amid shouts and dancing, the anthropologist swallows some sinew. Later that night, beside a dying fire, she writes, "Magic arises every night and every day." 
Later still, as she fades into sleep, the jaguar leaps,

runs her down and with one swipe

mauls her like some jungle peccary.

His yellow eyes transfix her. On padded feet,

he crouches, all coiled spring and gaping jaw.

When at last he bites down, a glacial fear

ripples into her bone marrow.

He rends his prey, shakes it side to side, nudges her carcass with his nose,

rolls near her broken neck, arching his back.

Nothing in her notebook will save her

from the peculiar dangle in his mouth.

He trots away to a private place

to devour his catch, the true, arcane meat.

Now in the surrounding night, she sways

in her hammock, eyes wide, the feline dream

scampering through the anthropologist's mind.

She envisions the jaguar's sleek back,

the smell of his eyes and stark whiskers,

the raspy gush of his deep breath

as he runs full stride toward her heart.

She is trying to sleep but the dream stares.

Her breath shortens. She shifts in her body,

her heart buried like a chewed up bone,

splintered, strewn, splotched in dried blood.

She opens her eyes to the hut's darkness.

"I am staring inside a dream," she thinks.

Alone, thralled, the anthropologist heaves.

This draft comes much later. It has been reworked and discussed with a few poet friends with whom I share work. In this draft, a tighter form has appeared. I have five seven-line stanzas, a form that began to appear naturally in Version IV.I have a completed ending to the poem that comments on the state of the anthropologist. The narrative flow of the poem has strengthened; it is steady, sure of itself as there is a story to tell and a perspective to the telling. 
At this stage of the revision process, it is time to scrutinize every single word in the poem. Words matter. At this stage of revision every word in every line counts, but I want to focus on the last line of this draft. There are two words that matter greatly: "thrall" and "heave." Ezra Pound often repeated a line he heard that meant everything to him: "Get a dictionary and learn the meaning of words"(Ford, date unknown/1971,p. 179). This is an absolute truth for a poet.

The word "thrall" in the last line intrigues. I use the noun as an adjective. It is a literary word, for sure, and it aptly describes both the emotional and the dream state of the anthropologist. Balancing "thralled" is the word that ends the poem, "heaves." This verb is a harsh one and has uncomfortable connotations. Does this work? Do I want to end a poem on such a physical note? Will using such a word complete the poem? Let me just say that I walked around thinking about these questions off and on for well over a year while the poem sat in my desk drawer.

Students find themselves arguing about the use of these words, but they also find that this discussion leads to other issues with the poem. They begin to revise the entire draft on account of such specific talk about two words. Their investment in the piece is complete; their wrestling with this version of the poem adumbrates their own revision process.

\section{[Version VII]}

\section{Jaguar Meat}

Choice, that poisoned dart. In the jungle, nothing is a dream and nothing is a nightmare; night strikes and fires blaze, the dead cat cooks. Amid shouts and dancing, the anthropologist swallows the meat. Later that night, beside a dying fire, she writes, "Magic happens every night and every day."

Later still, as she fades into sleep, the jaguar leaps, runs down her soul and with one swipe mauls it like some jungle peccary. His spike-like eyes transfix her: his crouch, his padded feet, his sudden spring and gaping jaws. 
His bite into her dream carries a fear

which ripples into her bone marrow.

He rends her soul like prey, shaking it side to side:

its limp bounce as he drops it,

as he nudges it with his nose,

rolls it, arching his back:

its peculiar dangle from his mouth

as he trots away to a private place

to devour his catch - true, arcane meat.

The anthropologist sways slightly in her hammock,

eyes wide in the surrounding night. The dream

scampers like a feline through her mind.

She recalls riding the jaguar's back

sniffing his shoulders, the raspy gush

of his deep breath as he runs into her own heart.

She tries to sleep but the dream keeps staring back.

Her breath shortens; she shifts her body.

Her heart feels like a chewed up bone,

splintered and strewn, splotched with its own dried blood.

She opens her eyes to the hut's darkness.

I am staring inside a dream, she thinks.

Alone, thralled, the anthropologist sighs.

Students always ask, how to know when to end a poem. I usually smile and say, "You usually get this feeling in your gut." They smirk and go back to their work. There is that apocryphal quote, attributed to the French poet Paul Valéry, that "a poem is never finished, [it is] only abandoned" (date unknown). That is true, to an extent. Usually, the writer will recognize when a poem ends or will just go on to something else.

This version (by no means the last) shows several changes to lines to adjust for rhythm and sound. Stanza two has changed (again) for the better, I think, as have stanzas three and four. Line four in stanza five I do not like; I like the line in the same stanza from version VI, actually. I took out the quotation marks to keep the internal nature of the thought. These issues of sound and rhythm, stanza changes, punctuation considerations become in-depth discussions for the students. They are now fine-tuning their own ideas about the poem's progress. 
Most important for me is the fact that I came up with a substitute verb for "heaves." "Sighs" is a gentler verb, easier to digest (no pun intended) perhaps. It changes the poem, makes it less haunting, I feel. I like "heaves." Poems do not have to be comfortable and I sometimes think "sighs" is a little too comfortable. I am still undecided about this change. I read a later version of the poem aloud at readings now, and I just wait and see which word I will use when I read the line. But now I do know that with whichever word I decide to use, the poem has ended.

Is this version of the poem finished? No, not at this point. But I like where I am headed. At this stage of the session, students find themselves totally immersed in the poem's direction. In fact, some are adamant about where and how I should proceed. ${ }^{4}$

After engaging with the revision process, students, whether pre-service teachers in English Education programs at the undergraduate or graduate level, or public and private school teachers, come away with the knowledge that re-visioning a poem, reflecting upon it, is a necessary task. Through a modeling of the revision process, they experience coming at a poem from different perspectives. They see that one cannot gain perspective without the benefit of time, distancing, and a sense of trusting one's own instincts. These are not easy lessons, and analyzing how a poem moves through the revision process gives them a glimpse into the nature of the beast. And the beast is mysterious. As Jim Provencher says, "Poetry, especially lyrical poetry, may be the most impervious to external editing" (J.Provencher, Personal communication, August 10, 2010). That's why students often do not think their poems need to be revised at all.

Students tend to think poems come into being whole and that's it. Interestingly, poets oftentimes claim this miracle, but it usually is not true, especially after scholars begin digging around. A poet is mighty lucky if he or she ever gets struck by lightning in that way. Though it does happen on occasion. But the reality is that poems are usually revised in some way; they are brought into being. In this sense, when one engages in revising a poem, one is a sort of midwife to it, as Provencher would say. Think of Pound's detailed editing of Eliot's "The Wasteland."

Through revision, my poem developed over time. That is the significant ingredient. Revising helps students stay in the poem and look at the words and think about them. Additionally, revision requires both a critical detachment and a letting go 
of sorts. We might call this letting go risk taking. These two components of revision embody the cognitive and emotional aspects of learning. ${ }^{5}$

Revision also allows student writers (all writers) to play with language. I played with my poem, but within the bounds of word choice, syntax, details, and a host of other aspects of a poem. We must not forget that revision is a type of play"not entertainment but play... a structured type of freedom" (p. 57), as Baron and I like to point out. Revision allows the writer "room to see how something might work differently" (p. 57). Also, I might add, it is just plain fun, as Provencher would say, "to edit and scrutinize the work of others" (J.Provencher, personal communication, August 10, 2010).

For students especially, revising a poem allows them the freedom to think about and play with words, a type of freedom with language they seldom are allowed to exercise in a school setting, especially in an English classroom. Since revision is a significant teaching tool that affords the writer "latitude and permission to feel how something can emerge over time" (p. 57) and since, for all poets, revision is paramount, I say to my students, "Let's do it" and, above all, let's keep on doing it.

\section{Notes}

1. A writer can, theoretically, rewrite until one overwrites. In fact, a claim can be made that it is only through overwriting can one find the real poem or truly discover where one wants to go with a draft.

2. The subject of reflection and its relationship to revision deserves its own essay. Simply put: reflection is the grease that lubricates revision.

3. The title of a poem is a uniquely important topic, deserving close attention during the revising process.

4. Once, I asked a class that had gone through my revisions to do a creative writing exercise and write their own version based on their experience of analyzing my revisions. The results were fascinating. 
5. Risk and critical detachment, both inherent ingredients of creativity, are aspects of interiority that has been squeezed out of learning in our technocratic, standardized test-driven approach to learning in our schools. Why? Because these aspects of learning cannot be measured with statistics. Yet, no one will argue that creativity is composed of risk taking, failure, and critical detachment. Again, why? Because any major breakthrough in almost any field has involved these processes. Mike Rose, in his several books, discusses this very important aspect of learning.

\section{References}

Ford, F.M. (1971). Pound/Ford, the story of a literary friendship. Brita Lindberg-Seyersted (Ed.). New York: New Directions Books.

Porter, C. (1928). Let's do it, let's fall in love. Retrieved November 17, 2010, from http://en.wikipedia.org/wiki/Let's_Do_It,_ Let's_Fall_in_Love
Valéry, P. (date unknown). Retrieved November 17, 2010, from http://www.brainyquote. com/quotes/quotes/p/paulvalery 103777.html

Wormser, B., \& Cappella, D. (2004). A surge of language: Teaching poetry day by day. Portsmouth, $\mathrm{NH}$ : Heinemann.

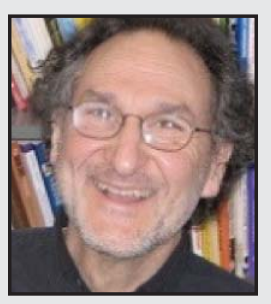

David Cappella is an Associate Professor of English at Central Connecticut State University where he teaches poetry and Young Adult Literature. He has co-authored with Baron Wormser two widely used textbooks, Teaching the Art of Poetry: The Moves and A Surge of Language:Teaching Poetry Day to Day. Cappella has led workshops on the teaching of poetry in public schools in Connecticut and throughout the United States, including the National Endowment for the Humanities. Cappella's poem series Gobbo: A Solitaire's Opera, won the 2004 Bright Hill Press Poetry Chapbook Competition and was a finalist for the 2006 Bordighera Prize and the 2008 Bright Hill Press Poetry Book Competition. 